\title{
Separate Development and Self-Reliance at the University of Pretoria
}

\author{
JANEKE THUMBRAN \\ PhD Candidate, History Department, University of Minnesota
}

In 2007, the University of Pretoria's office of community engagement arranged for a group of black women from a Pretoria township to travel to the whites-only town of Orania. ${ }^{1}$ Located in the rural Northern Cape province of South Africa, Orania was first established in 1963 as a housing area for the workers of a dam project. In 1991, it was repurposed as a homeland for Afrikaners unwilling to live in the 'new' South Africa. ${ }^{2}$ Based on the principle of self-werksaamheid, which residents translate into English as 'self-reliance', Orania goes against the long-held tradition in South Africa of employing black workers as domestic helpers, builders and the like, requiring the Afrikaners who live there to do their own labour. While the principle of selfreliance serves as a way to live separately from 'non-whites', it is also meant to reinforce self-sufficiency and solidarity among residents, ${ }^{3}$ and it is precisely this form of selfreliance that the black women were meant to learn from their visit.

Two arguments emerge from this encounter. The first is that the main objective of the University of Pretoria's current community engagement initiatives - to foster selfreliance, as demonstrated by the trip to Orania - does not depart significantly from this institution's history of alignment with separate development and its objective to create self-reliant black subjects during apartheid. By envisioning itself as a trustee of black communities in and around Pretoria, the university used the disciplines of sociology and social work to conduct studies and to intervene in black social problems with the intention of fostering self-reliance. The second argument is that the university's continued preoccupation with building self-reliant black communities in the post-apartheid present constitutes both a realignment with separate development and a convergence with the neoliberal restructuring of the state and the university in South Africa. These arguments seek to demonstrate that the university's approach to community engagement cannot be disentangled from the institution's direct involvement in implementing separate development and suggest that a critical engagement with the effects of separate development must be central to the critique of the university in South Africa.

In the 1880s, the first Act of parliament of the South African Republic (ZuidAfrikaansche Republiek, or ZAR) made provision for the establishment of a college 1 'Orania Community Lauded', News 24, 11 June 2007, http://www.news24.com/SouthAfrica/News/Orania-community-
lauded-20070611 (accessed 18 October 2017).
2 Ajax Delvecki and Alyson Greiner, 'Circling of the Wagons?: A Look at Orania, South Africa', Focus on Geography, 57(4) (2014),
164-173.
Ibid. 
that would provide a 'proper scientific education to the white population of the Transvaal.' ${ }^{4}$ However, it was only in 1907 in the aftermath of the Anglo Boer War that Jan Smuts decreed that a campus of the Transvaal University College (TUC), ${ }^{5}$ based in Johannesburg, be opened in Pretoria to serve the needs of the rural Afrikaans population. ${ }^{6}$ In 1910, the Pretoria campus of TUC became an independent institution, while the Johannesburg campus became known as the South African School of Mines and Technology, the forerunner of the University of the Witwatersrand. Although the ZAR's Act was intended towards establishing an institution that would be free from British and other Uitlander (foreign) influences, this only came to fruition when the Pretoria campus of TUC was re-established as the University of Pretoria and played a central role in cementing the notion of an Afrikaner identity. ${ }^{7}$

The establishment of the university in 1930 also coincided with a proliferation of Afrikaner cultural organisations, most of which were based in Pretoria. In addition, the administrative structure of the university, its disciplines, as well as the physical space of the campus, were all shaped by the reclamation of Pretoria as an Afrikaner capital in the early twentieth century. For instance, the buildings on campus were largely designed by architects invested in some form of Afrikaner identity. One of these architects, Gerard Moerdyk, not only served on the council of the university from 1930, but designed the Merensky Library on campus as well as the Voortrekker Monument, a significant symbol of Afrikanerdom that overlooks the city of Pretoria. ${ }^{8}$ By the 1940s, the university began to envision itself as a trustee of surrounding black communities and one of the first examples of its attempts to interact in this manner came in 1944, a year after the architecture department had been established.

The first head of the architecture department at the university, A.L. Meiring, developed a fascination for the design and building practices of what he identified as the 'AmaNdebele' community in the greater Pretoria area. He began to document the layout, design and painting practices of the settlement, taking colour photographs on an annual basis. When it became clear that the settlement would be moved, most likely due to its close proximity to a white suburb, ${ }^{9}$ Meiring took aerial photographs and involved his students in measuring and surveying the settlement, calling it a 'School of Architecture undertaking. ${ }^{10}$ By his own account, Meiring attempted to stop the removal of the settlement in order to preserve what he called the 'painstaking care in the execution of the bold patterns of coloured decoration on the walls. ${ }^{11}$ When his attempts to intervene in the removal proved futile, he negotiated with the Department of Native Affairs to find a new settlement. Established in 1953 in the Klipgat area

Roger Fisher, 'The Native Heart: The Architecture of the University of Pretoria Campus' in Hilton Judin and Ivan Vladislavić, eds., blank Architecture, apartheid and after (Rotterdam: NAi Publishers, 1998), 224.

The colloquial name of the University of Pretoria, TUKS or Tukkies, is derived from the acronym TUC.

Fisher, 'The Native Heart'.

Ibid.

Ibid.

Karel A. Bakker and Chris J. van Vuuren, 'Change and Continuity in Ndebele Earthen Architecture: Toward a Model for Conservation of Meaning in Architectural Decoration' in Leslie Rainer and Angelyn Bass Rivera, eds., The Conservation of Decorated Surfaces on Earthen Architecture (Los Angeles, CA: Getty Conservation Institute, 2006), 123-135.

10 A.L. Meiring, 'The Amandebele of Pretoria,' South African Architectural Record, 40(4) (1955), 27.

11 Bakker and Van Vuuren, 'Change and Continuity', 129. 
of greater Pretoria, ${ }^{12}$ the new settlement, named KwaMsiza, was developed into the first official 'Ndebele' cultural village and was marketed to tourists through Meiring's photographic documentation of houses, as well as clothing and jewellery. ${ }^{13}$

While Meiring's anthropological documentation was consistent with attempts to 'preserve the culture of the native' along with discourses around 'detribalisation', he also developed a long-standing relationship of trusteeship with the residents of both the old and the new settlements. By attempting to stop the removal of the settlement and negotiating with the Department of Native Affairs to provide alternative land, Meiring acted as a responsible trustee, ensuring the well-being of his wards. Involving his students in the study of 'Ndebele' architectural practices also made it possible for the architecture department to document life on the settlement for over half a century. ${ }^{14}$

Meiring's long-standing interaction with the residents of this settlement can be read alongside Smuts' 1942 lecture, 'The Basis of Trusteeship in African Native Policy'. Like Meiring, Smuts engaged with the discourse of 'detribalisation', suggesting that the movement of Africans into towns and cities called for a re-examination of the relevance of trusteeship. In his lecture, Smuts traces the foundation of trusteeship to the League of Nations, where a 'sacred trust' was imposed on the more 'advanced peoples of the world to look after the more backward. ${ }^{15}$ The fundamental aspect of trusteeship then, was the responsibility that the trustee had to protect his ward. What Smuts demonstrated in this speech was the desire among liberal whites to civilise Africans and bring them into the modern world. This notion of trusteeship as a relationship between guardian and ward and as the 'proper' state of affairs between white and black, on the African continent as a whole, formed the justification for separate development. Separate development, in turn, provided the solution to the 'Native Question' that liberalism had failed to resolve.

Thought of as the intellectual domain where the knowledge, strategies, policies, and justifications necessary to the maintenance of domination were fashioned ${ }^{16}$ and the 'response to the quagmire facing the South African state intent on reorienting and recasting the meaning of black subjectivity,' ${ }^{17}$ the Native Question was entangled with two liberal traditions that competed with each other throughout South Africa's colonial history. The first, known as Cape liberalism, was based on a progressivist-assimilationist project that sought to 'civilise' and 'uplift natives' toward

12 Ibid.

13 Joanna Grabski and Carol Magee, eds., African Art, Interviews, Narratives: Bodies of Knowledge at Work (Bloomington, IN: Indiana University Press, 2013).

14 As recently as 2001, the head of the architecture department, who referred to Meiring as the 'benefactor' of KwaMsiza, supervised his students as they conducted a detailed photographic survey of wall 'decorations' as well as comprehensive fieldwork to compile a genealogy of the various families in the settlement. See Bakker and Van Vuuren, 'Change and Continuity'.

15 Jan C. Smuts, 'The Basis of Trusteeship in African Native Policy' (public meeting under the auspices of the South African Institute of Race Relations, City Hall, Cape Town, 21 January 1942).

16 Adam Ashforth, The Politics of Official Discourse in Twentieth-Century South Africa (Ann Arbor, MI: Michigan Publishing, 2014), 1.

17 Premesh Lalu, 'Restless Natives, Native Questions', Mail \& Guardian, 26 August 2011, https://mg.co.za/article/2011-08-26restless-natives-native-questions (accessed 18 October 2017). 
full membership in colonial society..$^{18}$ The second tradition gave up the project of assimilation in favour of institutional separation, and came to be known as indirect rule. By the early twentieth century, the first tradition gave way to the maintenance of group differentiation as leading liberal intellectuals like Alfred Hoernlé began to see the 'multiracial' nature of South Africa as a problem that could ultimately not be solved through assimilationist strategies. In South African Native Policy and the Liberal Spirit, Hoernlé argued that

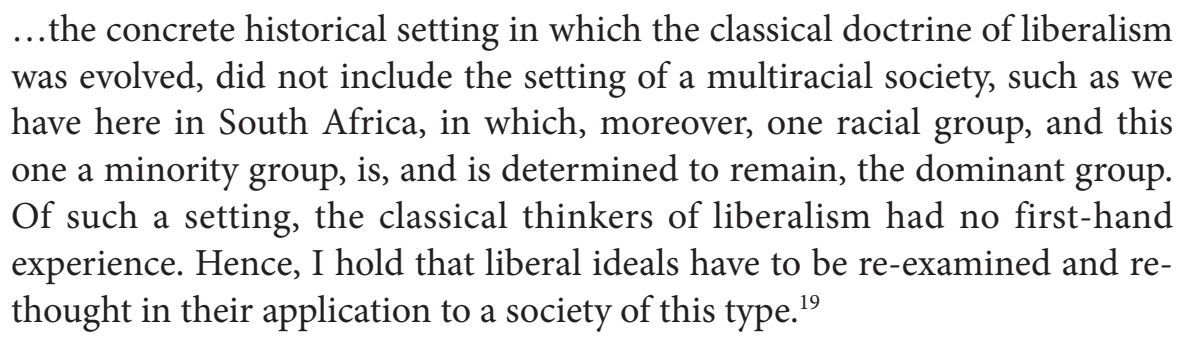

Hoernlé proposed the idea of 'total separation', which he believed could be made consistent with liberal principles to give each population group political rights within its 'own' society. ${ }^{20}$ By the mid-1940s, Hoernlés notion of 'total separation' was taken up by Afrikaner nationalists and reformulated as 'separate development'. It is also Hoernlés formulation of trusteeship - one that would prepare wards for independence in their own self-governing community ${ }^{21}$ and, by implication, solve South Africa's 'Native Question', which Afrikaner intellectuals at the University of Pretoria engaged with on the eve of the formal implementation of apartheid.

In 1934, Geoffrey Cronjé was appointed as a lecturer in the joint department of sociology and social work at the University of Pretoria. In 1937, he was promoted to professor, ${ }^{22}$ and by 1948 had written three influential texts that largely formed the basis of apartheid policy: 'n Tuiste vir die Nageslag (1945), Reverdige Rasse-apartheid (1947) and Voogdyskap en Apartheid (1948). ${ }^{23}$ In Voogdyskap en Apartheid, Cronjé engages with Hoernlés formulation of 'total separation' and positions trusteeship as the central principle of separate development. According to Cronjé, the relationship of trusteeship was based on the 'fact' that whites had reached a higher level of civilisation in South African society and, as such, had a responsibility to protect blacks and to help them achieve their own level of development and self-sufficiency. ${ }^{24}$ As a temporary relationship, trusteeship or voogdyskap was meant to be enforced only

18 Antina von Schnitzler, Democracy's Infrastructure: Techno-Politics and Protest after Apartheid (Princeton, NJ: Princeton University Press, 2016), 37.

19 Alfred Hoernlé, South African Native Policy and the Liberal Spirit: Being the Phelps-Stokes Lectures, Delivered before the University of Cape Town, May, 1939 (Cape Town: University of Cape Town Press, 1939), viii-ix.

20 Ibid., 101.

21 Ibid.

22 University of Pretoria, Ad Destinatum: Gedenkboek van die Universiteit van Pretoria (Johannesburg: Voortrekkerpers Beperk, 1960), 123.

23 Geoffrey Cronjé, 'n Tuiste vir die Nageslag (Johannesburg: Publicite Handelsreklamediens, 1945); Geoffrey Cronjé, William Nicol and E.P. Groenewald, Regverdige Rasse-apartheid (Stellenbosch: Christen-Studenteverenigingmaatskappy van Suid-Afrika, 1947); Geoffrey Cronjé, Voogdyskap en Apartheid (Pretoria: Van Schaik, 1948).

24 
until black South Africans no longer needed white support and guidance. ${ }^{25}$ This formulation of separate development and trusteeship was articulated by Hendrik Verwoerd in 1950:

...[i]f mixed development is to be the policy of the future in South Africa, it will lead to the most terrific clash of interests imaginable... The only possible way out is...that both [Bantu and European] adopt a development divorced from each other. That is what the word apartheid means. We cannot escape from that which history has brought in its train. However, this easiest solution for peaceful association, self-government and development, each according to its own nature and completely apart from one another, may, in fact, be taken as a yardstick whereby to test plans for getting out of the present confusion and difficulties... Obviously, in order to grant equal opportunities to the Bantu, both in their interests as well as the Europeans, its starting point is the Native territories...Our first aim as Government is...to lay the foundation of a prosperous producing community through soil reclamation and conservation methods and through the systematic establishment in the Native territories of Bantu farming on an economic basis... Side by side with agricultural development there must also come an urban development founded on industrial growth... In their establishment, Europeans must be prepared to help with money and knowledge, in the consciousness that such industries must, as soon as is possible, wholly pass over into the hands of the Bantu... Bantu working in these industries will then be able to live in their own territories, where they have their own schools, their own traders, and where they govern themselves. Indeed, the kernel of the apartheid policy is that, as the Bantu no longer need the European, the latter must wholly withdraw from the Native territories. What length of time it will take the Bantu in the reserves to advance to that stage of self-sufficiency and self-government will depend on his own industry and preparedness to grasp this opportunity offered by the apartheid policy for self-development and service to his own nation. ${ }^{26}$

In this speech, Verwoerd not only sees trusteeship as central to the implementation of separate development, but positions the creation of self-reliant black communities as the ultimate objective of separate development - articulated here in the terms 'own', 'self-sufficiency' and 'self-government'. Through the work of intellectuals like Cronjé, and an alignment with separate development, the University of Pretoria took on the task of guiding black communities in and around Pretoria towards selfreliance, largely through social research and social work intervention.

25 Ibid.

26 Selections from Verwoerd's speech ‘The South Africa Government's Policy of Apartheid' in Verwoerd Speaks: Speeches, 19481966, edited by A.N. Pelzer (Johannesburg: APB Publishers, 1966), 23-29. 
The focus on fostering self-reliant black neighbourhoods, particularly those on the urban periphery of Pretoria, was often accompanied by a particular understanding of 'community'. During apartheid, 'community' came to be defined in racial and ethnic ways through the workings of the state and its apparatuses. Even when understood in geopolitical terms to refer to localities and neighbourhoods where people live, it was racialised due to racial legislation and became synonymous with the socially enforced understandings of racial 'groups' - and especially as a stand-in for the signifier of 'non-white'. For instance, the Department of Community Development was the institution through which the Group Areas Act was enforced and which carried out forced removals, ${ }^{27}$ leaving black South Africans with little choice but to craft their 'own' self-reliant neighbourhoods.

At the University of Pretoria, 'social' disciplines like sociology and social work formed the means through which to instil self-reliance in blacks. University-trained sociologists were preoccupied with identifying black social problems, as well as highlighting the 'inability' of the 'community' to solve those problems. More particularly, sociological studies were used to pre-empt any other potential obstacles to the achievement of self-reliance, such as poor housing and a high population growth.

In 1966, T.J. van der Walt, a master's student, conducted a sociological study on housing conditions in Eersterust. Like many other townships in Pretoria, Eersterust was created when residents were forcibly removed from Marabastad - an urban community in the heart of the city. Although forced removals had already begun with the establishment of Atteridgeville in 1939, most remaining residents of Marabastad were finally moved in the 1960 s and 1970s - relocated to various racially designated townships on the outskirts of the city. ${ }^{28}$ Eersterust became a consistent site of social research and intervention for the University of Pretoria, as well as for social welfare organisations like Child Welfare.

Van der Walt's 1966 sociological study set out to explore the condition of 'NonEuropean' (NE) housing in Eersterust and to measure residents' satisfaction with both economic and subeconomic units. Van der Walt's hypothesis was that poor housing conditions, as well as dissatisfaction with the housing that was provided by the state, had implications for the social welfare of the residents. ${ }^{29}$ This observation was premised on D.M. Calderwood's ${ }^{30}$ belief that '... proper housing... will establish family groups who will have to shoulder their responsibilities and will create a better national economy. A properly housed community will cost the taxpayer less; health, crime and productivity in industry will all be affected. ${ }^{31}$

Van der Walt conducted surveys with the residents of 260 units - both economic and subeconomic ${ }^{32}$ - while also assessing their living conditions. His findings were

Noëleen Murray, 'Remaking Modernism: South African Architecture in and out of Time' in Noëleen Murray, Nick Shepherd and Martin Hall, eds., Desire Lines: Space, Memory and Identity in the Post-Apartheid City (London: Routledge, 2007), 43-66.

28 J.F.C. Clarke, A Glimpse into Marabastad (Pretoria: Leopardstone Private Press, 2008), 13.

29 T.J. van der Walt, 'Kleurlingbehuising in Eersterust, Pretoria: 'n Sosiologiese ontleding met besondere verwysing na onwenslike behuisingstoestande en die houding van die kleurlinge ten opsigte van hul behusingsomstandighede' (MA diss., University of Pretoria, 1966).

30 Calderwood was one of the architects of the NE housing series.

31 In Van der Walt, 'Kleurlingbehuising in Eersterust', 3.

32 Ibid. 
that, while an overwhelming percentage of residents in subeconomic units were dissatisfied with their housing, ${ }^{33}$ overall housing conditions in Eersterust did not pose any obstacles to the social well-being of the residents, and, by implication, created favourable conditions for the achievement of self-reliance.

In 1967, another master's sociology student, A.S. du Toit, conducted a study on female reproduction in Eersterust. Through surveys with female residents, he sought to determine how many children women in Eersterust expected to have and how this expectation was shaped by factors such as class and religious beliefs. ${ }^{34}$ The motivation for the study was to establish a sense of how this urban black population might grow in the future - particularly if the women had been 'educated' on family planning ${ }^{35}$ but, more specifically, to determine the impact that population growth might have on the ability of this community to become self-reliant. ${ }^{36}$

When sociological studies were not highlighting social problems in black communities - or identifying potential obstacles to self-reliance - they were pointing to specific interventions that needed to be made. In the late 1970s, the former head of the department of social work and sociology at the University of Pretoria, J.E. Pieterse, served as the chairman of the committee for another sociological study on Eersterust. This study was conducted through the Institute for Sociological, Demographic and Criminological Research, part of the Human Sciences Research Council, at the request of Pretoria's Child Welfare office. The objective was to give an overview of all the social problems in Eersterust. By conducting house-to-house surveys, the researchers compiled a comprehensive volume on housing, household income, religious practices, fertility rates and family planning, but also focused on social problems such as 'illegitimacy', unemployment and crime, as well as the existence of several 'shebeens' in the township. Although the compilers of the report pointed out that the focus on black pathology provided a rather 'unbalanced' view of the community, the ultimate objective was to point to the lack of 'community', and to make a set of recommendations through which self-reliance could be achieved, particularly through social welfare and social work initiatives. ${ }^{37}$ For instance, the overall conclusion of the study was that residents needed support in order to 'help themselves' - they needed to be guided towards recognising that they themselves constituted the solution to their 'own' problems. ${ }^{38}$ In order to 'help the community help itself', the University of Pretoria established a unit at the Child Welfare office in

34 Andries Stephanus du Toit, 'Die Vrugbaarheidsverwagtinge van Kleurlinge in Eersterust, Pretoria: 'n Bevolkingsosiologie Studie' (MA diss., University of Pretoria, 1967).

35 Ibid.

36 This kind of study was consistent with broader trends in the discipline of sociology at Afrikaans universities at the time, where the focus of sociological research fell overwhelmingly on criminology (black deviance) and demography (black overpopulation). These trends were especially reflected in the department of sociology and social work at the University of Pretoria, where criminology was introduced as a field of study in 1948 and became a separate department under the leadership of Geoffrey Cronjé in 1960. By the 1980s, the department had become increasingly invested in demography and introduced several new courses in this area. See Heribert Adam, 'The Vocation of a Sociologist in South Africa' in John Rex, ed., Apartheid and Social Research (Paris: Unesco, 1981), 115-127.

37 Johann Morgendahl Lötter, Eersterust: 'n sosiologiese studie van 'n kleurlinggemeenskap (Pretoria: Suid-Afrikaanse Raad vir Geesteswetenskaplike Navorsing, Instituut vir Sosiologiese, Demografiese en Kriminologiese Navorsing, 1979). 
Eersterust in January 1987, where social work students were placed to complete their practical training. ${ }^{39}$

In addition to guiding the residents of black communities towards self-reliance, the University of Pretoria also saw itself as the trustee of black institutions. In the 1940s, the black institution Kolege ya Bana ba Afrika was established in Pretoria. Although the university did not assist in the establishment of this college, it did provide instructional support by sending some of its own staff to teach there. ${ }^{40}$ By 1948 , the University of Pretoria was tasked with bringing the black college under its direct control but the senate voted against the idea and instead proposed that a university be established in the north of the Transvaal, under the trusteeship of the University of Pretoria. In a memorandum on the issue, Professor P.J. Coertze wrote that,

[d]ie Senaat is diep onder die indruk...dat daar ook van Afrikanerkant op die gebied van die hoer onderwys 'n aandeel behoort geneem te word in die opleiding en kweking van Bantoleiers. (The Senate is under the impression that Afrikaners should have a share in the education and training of Bantu leaders. $)^{41}$

The university demonstrated this vested interest in the training of black leaders by not only establishing Medunsa - the Medical University of South Africa, in the then bantustan of Bophuthatswana - but also by staffing this institution with its own white professors and administrators. ${ }^{42}$

As early as 1938, a committee was appointed at the University of Pretoria to investigate the possibility of establishing a medical school for 'non-whites'. By 1966, an academic hospital had already been set up in Ga-Rankuwa - a township meant to house the workers of the nearby industrial area of Rosslyn ${ }^{43}$ - and in the 1970s, the vice-chancellor of the University of Pretoria, Adriaan Pelzer, ${ }^{44}$ lobbied for 350 hectares to plan the spacious grounds that would be made into Medunsa. In 1976, the university selected members of its own medical faculty to serve on the board of Medunsa, appointing the dean of the school of medicine, Professor H.W. Snyman, as the head of the planning committee. ${ }^{45}$ When Medunsa was officially opened in the same year, Snyman was appointed as the vice-chancellor and, in 1977, twelve former students or current staff at the University of Pretoria were also appointed as professors. ${ }^{46}$

39 S.M. van Staden, E.A.K. Hugo, I.J.J. van Rooyen and W.F. van Delft, eds., Maatskaplike Werk Oor Sestig Jaar: Feesbundel van die Departement Maatskaplike Werk Universiteit van Pretoria (Pretoria: Owen Burgess, 1989).

40 F.J. du Toit Spies, D.H. Heydenrych and University of Pretoria, Ad Destinatum II 1960-1982: 'n Geskiedenis van die Universiteit van Pretoria (Pretoria: University of Pretoria, 1987).

41 Ibid., 414 (my translation into English).

42 Ibid.

43 Ibid.

44 Adriaan Pelzer served as the vice-chancellor of the university from 1974 to 1980 . He was also the former head of the history department and authored Die Afrikaner-Broederbond: Eerste 50 Jaar (Cape Town: Tafelberg, 1979) and edited Verwoerd Speaks: Speeches 1948-1966 (Johannesburg: APB Publishers, 1966).

45 C.J. Mieny and D.H. Heydenrych, UP Geneeskunde 50: 'n geskiedenis van die Fakulteit Geneeskunde van die Universiteit van Pretoria, 1943-1992 (Pretoria: Gutenberg Press, 1993).

Ibid. 
This commitment to develop black leaders and institutions was expressed in Verwoerd's own understanding of the purpose of both white and black universities:

I want to talk to you this morning about something which belongs to you. Two things belonging to you I want to link together: the university and the future...Before developing this thought a little further by looking back on our past, I first want to interpose and touch upon two matters. The first is that what I have just said regarding the significance of the university to us as a white nation will be equally true of their own universities to the Bantu population of South Africa. When own university institutions for the Bantu are established in their own areas it will also become evident that the different Bantu national communities will only obtain this real value of universities and university-trained persons if these institutions, lecturers and students emanate from their midst, if the institutions are built and the students study in their own communities and hence areas, and if they stay among their own people to serve them. Those who attack us in South Africa when we give to the Bantu population their own university institutions and thereby ensure that their leaders are not weaned away by going to the white universities and community as pupils, do not realize that it is the greatest service on earth that a guardian can render, namely to allow the nation and community under his care to retain its young savants and to let them become its leaders. ${ }^{47}$

In Verwoerd's assessment then, white universities were to ensure the selfdetermination of white South Africans, while black universities were responsible for developing self-reliance amongst their own people. However, by suggesting that a guardian ought to allow the community under his care to develop its own leaders, Verwoerd placed an additional responsibility on white universities: to secure their institutions for future white generations, while acting as a trustee in both the establishment and administration of black universities.

In the post-apartheid period, the University of Pretoria still seeks to foster black self-reliance - now through its community engagement initiatives. Although this deeply embedded practice constitutes a return to this institution's history of alignment with separate development, it also converges with the post-apartheid state's neoliberal agenda, as well as the restructuring of the university under the mandate of 'transformation'.

On 15 March 2005, then South African president Thabo Mbeki was invited to open the Oliver Tambo Law Library at the University of Pretoria. At this opening, he praised the university for its transformation from a white Afrikaans institution into one that 'welcomes all, irrespective of race, gender, creed or nationality'. He went on

47 Hendrik Verwoerd, 'Address on the Occasion of the Opening of the Academic Year at the University of Stellenbosch, February 25, 1959' in Verwoerd Speaks: Speeches 1948-1966, edited by A.N. Pelzer (Johannesburg: APB Publishers, 1966), 248, 250. 
to state that the university is not only a 'truly South African university', but that it has also 'correctly positioned itself as an African university.' ${ }^{48}$ Mbeki's comments were in line with the University of Pretoria's attempts to transform the 'traditional Afrikaans character of the institution' to make way for 'a South African university community that undid every form of discrimination based on colour, language, gender and creed' ${ }^{4} 9$

These attempts at 'transformation' in the post-apartheid era are tied to the restructuring of universities through a series of strategic plans, generally aimed at equity and the democratisation and increased efficiency and effectiveness of the institution. ${ }^{50}$ The University of Pretoria's most recent strategic plan, UP 2025, ${ }^{51}$ was publicised in 2012 and is aimed at developing the institution into a leading research-intensive university through carefully planned and managed growth. ${ }^{52}$ By 2025 , the university has set its sights on being 'recognized internationally for its quality, relevance and impact, developing people, creating knowledge and making a difference locally and globally'. ${ }^{53}$ This vision is supported through the implementation of strategic goals, which include pursuing excellence in teaching and learning, increasing access, throughput and diversity, and strengthening the university's impact on economic and social development. ${ }^{54}$

The concern with strategy, performance and measurement is consistent with postapartheid universities that have been shaped by ideas of excellence, as well as forms of managerialism, ${ }^{55}$ corporatism and a need to serve the public good. These notions are also tied to enhancing the relevance of universities in the twenty-first century, particularly through an engagement with present-day socioeconomic challenges, often subsumed under concepts such as 'community engagement', 'community service', 'university-community partnership', 'social responsiveness', 'academic citizenship', 'service learning' and a number of other aliases. ${ }^{56}$ One of the clearest statements on increasing the relevance of universities through community engagement comes from the South African Department of Education's White Paper 3, which states that universities need to 'promote and develop social responsibility and awareness amongst students of the role of higher education in social and economic development through community service programmes', in addition to their 'traditional' devotion to teaching, learning and research. ${ }^{57}$

48 Flip van der Watt, Tukkies Oorskou Sy Eerste Honderd Jaar, 1908-2008 (Pretoria: University of Pretoria, 2008 ), 1.

49 P.B. van der Watt, ed., Ad Destinatum: Historical Developments and Events at the University of Pretoria $1993-2000$ (Pretoria: University of Pretoria, 2002), i.

50 Ibid.

51 See http://www.up.ac.za/media/shared/Legacy/sitefiles/file/publications/2012/eng/strategic_plan_v11_13feb.pdf (accessed 19 October 2017).

52 Tukkie: Alumni Magazine of the University of Pretoria 18(1) (March 2012).

53 Ibid., 4.

54 Ibid.

55 John Clarke, 'The Managerialised University: Translating and Assembling the Right to Manage' in John Clarke, Dave Bainton, Noémi Lendvai and Paul Stubbs, Making Policy Move: Towards a Politics of Translation and Assemblage (Bristol: Policy Press, 2015), 95-130.

56 See Wilson Akpan, Gary Minkley and Jayshree Thakrar's introduction to the special issue of South African Review of Sociology, 'In Search of a Developmental University: Community Engagement in Theory and Practice', 43(2) (2012), 1-4.

57 South African Department of Education, White Paper 3: A Programme for the Transformation of Higher Education, 1997, https:// www.gov.za/sites/default/files/18207_gen1196_0.pdf (accessed 19 October 2017), 9. 
At the University of Pretoria, community engagement has been structured by the institution's desire to be globally competitive, increasingly efficient - in its administration, but also in its provision of 'services' to students ('clients') - and to be recognised for its impact on local communities. Working in collaboration with private partners and/or stakeholders, community engagement is seen as being a move towards closer relationships with local black communities. However, despite the use of participatory approaches, notions of 'expertise', 'upliftment' and 'outreach' predominate. The purpose of community engagement then is to provide skills to socalled disadvantaged communities by claiming to empower them, and it forms an opportunity for the university to foster the self-reliance presumably lacking in black communities.

While the notion of 'self-reliance' has emerged as a central principle in the University of Pretoria's community engagement initiatives, it has also been at the centre of the post-apartheid government's strategy of social and economic transformation. When the African National Congress (ANC) came to power in 1994, it planned to implement the Reconstruction and Development Programme but abandoned this strategy in 1995. In 1996, it implemented the neoliberal Growth, Employment and Redistribution (GEAR) strategy, which emphasised public-private partnerships and shifted a large part of the responsibility to provide public services onto the private sector. With the implementation of GEAR came the notion of self-reliance: the capacity of people and 'communities' to operate self-reliantly in partnership with private organisations. ${ }^{58}$

A contemporary example of the state's articulation of self-reliance can be seen through the Victoria Mxenge Housing Project, in which a group of women from Khayelitsha started a savings scheme to build their own houses. In addition to making small daily contributions to the scheme, the women secured a government subsidy and began building their own houses on a piece of donated land in Philippi. The initiative taken by these women is precisely what the state had in mind when it developed and introduced the People's Housing Process (PHP) - a housing strategy meant to invite communities into housing delivery by getting them to drive the process themselves. In the most recent iteration of PHP, known as the Enhanced People's Housing Process, communities - black women in particular - are encouraged to become self-reliant by creating saving schemes and constructing their own houses. ${ }^{59}$

The state's articulation of self-reliance - demonstrated here through housing policy - forms part of the neoliberal reforms that were introduced in South Africa in the late apartheid period and that have been central to the restructuring of universities in South Africa. At the University of Pretoria, these neoliberal reforms have converged with this institution's history of alignment with separate development to continue with the objective of producing self-reliant black subjects - now in the post- 
apartheid period. Nothing demonstrates this more clearly than organising for a group of black women from Eersterust to travel to Orania.

The significance of the visit to Orania does not merely lie in the fact that a group of black women were taken to a white separatist town to be taught about self-reliance. It is that Orania's very existence rests on Verwoerd's vision of separate development and its objective of crafting self-sufficient black communities. Verwoerd's image can be seen throughout Orania: from a statue that overlooks the town, to one at the entrance of a museum dedicated to his life and memory. The original founder of the Orania movement, under which the town was established, was also Verwoerd's son in law and taught theology at the University of Pretoria.$^{60}$ In addition, residents see themselves living according to the principles of separate development, as demonstrated through the comment,

I see nothing wrong with apartheid...[o]f course you get the petty apartheid: 'You use this toilet I use that toilet', I don't think that was necessary but the real apartheid as Dr Verwoerd saw it, there was nothing wrong with it. ${ }^{61}$

While Orania functions as a site of separate development, it has also partnered with the neoliberal state, having received money from the ANC government for the construction of roads and infrastructure in the area.$^{62}$ This convergence of separate development and neoliberalism is mirrored in the University of Pretoria's practices, and particularly in its attempt to foster self-reliance through its community engagement initiatives. The current material and epistemological crises in South African universities not only call for a serious engagement with the effects of neoliberalism and separate development, but also with the ways in which neoliberalism has shaped and reworked institutional practices in the post-apartheid present.

Christopher S. Wren, 'A Homeland? White Volk Fence Themselves in: A Tiny Band of Afrikaners with Desperate Words', New York Times, 8 May 1991.

61 Pumza Fihlani, 'Inside South Africa's Whites-Only Town of Orania', BBC News, 6 October 2014, http://www.bbc.com/news/ world-africa-29475977 (accessed 18 October 2017).

62 Suzanne Daley, 'Afrikaners Have a Dream, Very Like the Old One: To Keep Blacks out, ..., New York Times, 4 May 1999. 